\title{
Extrusion with Thermostable $\alpha$-amylase Injection as Pretreatment Method for Ethanol Production from Corn Starch
}

\author{
Lin Myat and Gi-Hyung Ryu* \\ Department of Food Science and Technology, Kongju National University, Yesan, Chungnam 340-802, Korea
}

\begin{abstract}
Pretreatment technologies have been developed to increase the bioconversion rate of biomass into fermentable sugar. The objective of this research was to investigate the effect of extrusion with thermostable $\alpha$-amylase injection at different melt temperatures 95,115 and $135^{\circ} \mathrm{C}$ on functional properties, ethanol content and conversion (\%) of corn starch extrudates. Saccharomyces cerevisae (ATCC 24858) was used for ethanol production. In the present study, significant increase in ethanol production was achieved by the injection of thermostable a-amylase during extrusion process at melt temperature $115^{\circ} \mathrm{C}$. The data clearly showed that thermostable $\alpha$-amylase injection gave significantly increased $(p<0.05)$ ethanol content at melt temperature $115^{\circ} \mathrm{C}$ from fermentation period from 24 to 48 hr. Industrial bio-ethanol production by direct fermentation following extrusion with thermostable $\alpha$-amylase injection and omitting the saccharification step will be very effective in reducing ethanol production costs in countries like U.S Therefore, ethanol production from extruded corn starch with thermostable $\alpha$-amylase injection is a significant finding that could be applied to improve bioconversion rate for ethanol production.
\end{abstract}

Keywords: Extrusion process; Thermostable a-amylase; Corn starch; Ethanol

\section{Introduction}

Starch-containing crops form an important constituent of the human diet. Besides the use of the starch-containing plant parts directly as a food sources, it is used as chemical or enzymatic processes into a variety of different products such as starch hydrolysates, glucose syrups, fructose, starch of maltodextrin derivatives, or cyclodextrins. Only few plants are able to produce industrial starch. The major industrial starch sources are maize, tapioca, potato, and wheat. Sugar sources such as starch and cellulose are potential candidates for ethanol production, biodiesel, and organic chemicals. Ethanol is produced through fermentation of various grains (i.e. corn, sorghum, barley, and wheat) and sugar crops (i.e. sugar cane, sugar beets and sweet sorghum) with $\mathrm{CO}_{2}$ as a by-product. However, several factors have been suggested to be responsible for the low starch digestibility [1].

The production of chemicals and biochemical from renewable biomass faces significant technical and economic challenges at present. Its success depends largely on the physical and chemical properties of biomass, pretreatment methods, efficient microorganisms and processing conditions. Therefore, pretreatment technologies have been developed to increase the bioconversion rate of biomass into fermentable sugar.

Among these methods, extrusion has been widely used method in which several unit operations are performed simultaneously during extrusion process. The major advantages of extrusion include increased digestible starch fraction, reduced molecular weight of bio molecules, creation of free sugars, and changes in the native structure of biomolecules and reduced viscosity of fermentation broth when using extruded products during fermentation [2]. The extrusion also makes starch liquefaction and has good digestibility and improved functional properties with regard to food and beverage applications. Depending on the intensity of the stress involved, it might also cause thermal degradation of sugars and amino acids. Increased ethanol production has also been observed as a result of extrusion [3].

Recently, the use of an extruder has been investigated as a continuous reactor for enzymatic modification of starches. Extrusion process has been applied for liquefying different kinds of starches to reduce saccharification time for glucose syrup production or fermentation substrate preparation. Barley starch was liquefied using Bacillus licheniformis $\alpha$-amylase in a twin-screw extruder and then the liquefied syrup was saccharified using Aspergillus niger glucoamylase [4]. Saccharification time can be reduced when starch is pre-treated using extrusion-liquefaction technology [5]. The enzymatic hydrolysis provides many advantages over acid hydrolysis and is an important industrial process that consists of three steps: gelatinization, liquefaction and saccharification. In industry, a jet cooker is used to gelatinize starch by mixing the starch slurry with steam under pressure at $100-175^{\circ} \mathrm{C}$ [6]. Usually, thermostable $\alpha$-amylase is used by mixing with starch before passing through the jet cooker [7]. Industrial gelatinization process in a jet cooker is usually carried out with $30-35 \%$ dry solids starch slurry. Increasing the substrate concentration during the enzymatic hydrolysis can yield higher productivity, and higher enzyme stability $[8,9]$. However, when the starch concentration increases, the temperature required to increase for complete gelatinization [10]. Moreover, the viscosity of the starch slurry increases with increasing starch content and this complicates further processing. Conventional jet cookers cannot be used anymore at high substrate concentrations due to the increased viscosity. Since the gelatinization temperature increases, addition of the enzyme during the gelatinization process is unfavorable, because it can lead to enzyme inactivation. A different process is therefore needed to handle more concentrated starch slurries. Therefore, extrusionenzyme liquefaction appears to be suitable for this purpose. Biomass pretreatment is critically important for cost-effective hydrolysis and

*Corresponding author: Gi-Hyung Ryu, Department of Food Science and Technology, Kongju National University, Yesan, Chungnam 340-802, Korea, Tel: 82-41-330-1484; Fax: 82-41-335-5944; E-mail: ghryu@kongju.ac.kr

Received February 05, 2013; Accepted March 25, 2013; Published March 28 2013

Citation: Myat L, Ryu GH (2013) Extrusion with Thermostable $\alpha$-amylase Injection as Pretreatment Method for Ethanol Production from Corn Starch. J Microb Biochem Technol 5: 047-053. doi:10.4172/1948-5948.1000099

Copyright: @ 2013 Myat L, et al. This is an open-access article distributed under the terms of the Creative Commons Attribution License, which permits unrestricted use, distribution, and reproduction in any medium, provided the original author and source are credited 
fermentation of feed stock into ethanol. Chemical (acid and alkali) pretreatments are expensive, require chemical resistant reactors and produce hydrolysis products that inhibit the subsequent fermentation process. One of the major problems in the production of ethanol is the amount of energy required in the conversion of starch to fermentable sugars, particularly during the gelatinization and liquefaction processes. The gelatinization of starch consumes up to $30 \%$ of the total energy needed for alcohol fermentation [11]. Therefore, it is necessary to develop environment-friendly, cost-effective and highly efficient enzymatic hydrolysis process for economic ethanol production [12].

Yeung [13] reported that dextrose equivalent (DE) of extruded barley flour with thermostable $\alpha$-amylase injection decreased at 120 and $140^{\circ} \mathrm{C}$ due to inactivation of $\alpha$-amylase at these temperatures. Furthermore, the efficiency of enzyme action was found to be decreased at temperature below $80^{\circ} \mathrm{C}$ (due to a low energy of activation) and beyond $150^{\circ} \mathrm{C}$ (due to enzyme denaturation). In view of these limitations, there is a continuing demand to improve the stability of enzymes to meet the requirement for specific application. Therefore, this study was conducted in a twin-extruder with a lower enzyme concentration (less than 1\%) to determine the effect of thermostable $\alpha$-amylase injection at different melt temperatures 95,115 and $135^{\circ} \mathrm{C}$ on functional properties and the production of ethanol from extruded corn starch with thermostable $\alpha$-amylase injection.

\section{Materials and Methods}

\section{Materials and chemicals}

Corn starch provided by Samyang Genex Co. (Korea) was used for extrusion. The thermostable a-amylase (Termamyl-supra 120 L; Novozyme, Bagsvaerd, Denmark) was used for injection during extrusion process. Phenol and sulfuric acid were purchased from Daejung Chemicals and Metals Co. Ltd. (Korea) for total sugar determination. Pepsin (Samjun Chemical Ind. Co., Korea) was used for determination of protein digestibility. For determination of free amino nitrogen (FAN), the necessary chemical reagents were purchased from Sigma Aldrich Co. Ltd.

\section{Extrusion process}

Extrusion was conducted in twin-screw extruder (THK31T, Incheon Machinery Co., Incheon, Korea). All experiments were conducted at screw speed of $150 \mathrm{rpm}$, feed rate of $120 \mathrm{~g} / \mathrm{min}$, water injection rate of $31.02 \mathrm{~g} / \mathrm{min}$, and the die diameter of $3 \mathrm{~mm}$. The $\alpha$-amylase (Termamylsupra $120 \mathrm{~L}$ ) was used at a concentration of $0.0675 \%(w / w)$, and added to a $0.675 \mathrm{~g} / \mathrm{kg}$ dry corn starch. Feed moisture content was adjusted to $30 \%$. Melt temperature was controlled at 95,115 and $135^{\circ} \mathrm{C}$ with and without thermostable $\alpha$-amylase injection. The corn starch extrudates were directly dried in an oven at $80^{\circ} \mathrm{C}$ for $4 \mathrm{hr}$ and grinded into powder less than $0.5 \mathrm{~mm}$ particle size and used as sample for functional properties analysis, and substrate for ethanol production.

\section{Reducing sugar and enzyme activity}

a-amylase activity was assayed by measuring the reducing sugar released during the enzymatic reaction. One unit of enzyme activity was defined as the amount of enzyme which produced $1 \mathrm{mM}$ glucose per minute. Residual enzyme activity was measured by incubating the extrudates suspension directly dissolved in $50 \mathrm{mM}$ phosphate-citrate buffer at $95^{\circ} \mathrm{C}, \mathrm{pH} 6$ for 10 minutes right after the extrusion process. Reducing sugar content was determined according to DNS method [14] using 3,5-dinitrosalicilic acid. Glucose solution was used as standard.

\section{Functional properties}

Moisture content was analyzed by the standard method [15]. Total sugar content was measured using phenol-sulfuric acid method [16]. Two grams of sample was mixed with $20 \mathrm{~mL}$ of $70 \%$ ethanol solution and it was extracted at $80^{\circ} \mathrm{C}$ for $2 \mathrm{hr}$. Then, the extracted mixture was centrifuged at $3000 \mathrm{rpm}$ for 20 minutes. The supernatant was decanted and the volume was made up to $40 \mathrm{~mL}$ with distilled water. The sample solution $(1 \mathrm{~mL})$ was mixed with $1 \mathrm{~mL}$ of $5 \%$ phenol solution and 5 $\mathrm{mL}$ of concentrated sulfuric acid. The mixture was left for 15 minutes for standing at room temperature and the absorbance was read at 550 $\mathrm{nm}$ against the blank containing distilled water in place of sample. Glucose was used for standard solution. Reducing sugar content was determined as glucose according to DNS method [14].

Protein digestibility (pepsin digestibility) was carried out as described by Mertz et al. [17]. Two hundred milligrams of samples were suspended in $35 \mathrm{~mL}$ of pepsin solution $(1.5 \mathrm{~g}$ of enzyme/ $1 \mathrm{~L}$ of $0.1 \mathrm{M}$ potassium phosphate buffer, $(\mathrm{pH} 2)$ and incubated at $150 \mathrm{rpm}, 37^{\circ} \mathrm{C}$ for $2 \mathrm{hr}$. Pepsin activity was stopped by the addition of $2 \mathrm{~mL}$ of $2 \mathrm{M} \mathrm{NaOH}$ at the end of incubation period. The incubated slurry was centrifuged at $3000 \mathrm{rpm}$ for 15 minutes and the supernatant was decanted and the residues was washed with $10 \mathrm{~mL}$ of $0.1 \mathrm{M}$ potassium phosphate buffer ( $\mathrm{pH} 2$ ) and centrifuged as before. Washing the residues with $10 \mathrm{~mL}$ of $0.1 \mathrm{M}$ potassium phosphate buffer was done for twice and freeze-dried. The free-dried samples were then weighed and analyzed for nitrogen content.

The total phenolics content of raw and extruded corn starch at different melt temperatures was determined according to the FolinCiocalteu colorimetric method [18]. One gram of sample was extracted with $10 \mathrm{ml}$ of $80 \%(\mathrm{v} / \mathrm{v})$ methanol at room temperature for $12 \mathrm{hr}$. The mixture was centrifuged at $3000 \mathrm{rpm}$ for 30 minutes. $300 \mu \mathrm{l}$ of the supernatant was mixed with $1.5 \mathrm{ml}$ of $10 \%(\mathrm{v} / \mathrm{v})$ Folin-Ciocalteu reagent and vortexed thoroughly and allowed for 5 minutes for reaction. Then, the mixture was supplemented with $1.5 \mathrm{ml}$ of $(60 \mathrm{~g} / \mathrm{L})$ sodium carbonate solution and incubated at room temperature for $2 \mathrm{hr}$. The absorbance was measured at $765 \mathrm{~nm}$ against the blank containing $80 \%$ methanol. The concentration of total phenolics content in the extracts was determined as mg of gallic acid equivalent per gram of dry sample using equation obtained from the standard gallic acid curve.

\section{Free amino nitrogen}

Free amino nitrogen (FAN) was analyzed according to the European Brewery Convention Method [19] with modification. Raw and extruded corn starch powder $(150 \mathrm{mg})$ was mixed with $1.5 \mathrm{~mL}$ of deionized distilled water in a $1.5 \mathrm{~mL}$ micro centrifuge tube and vortexed and then centrifuged at 12,000 rpm for 20 minutes using a micro high speed centrifuge (Micro 17TR, Hani Science Industrial Co. Ltd., Korea). The supernatant $1 \mathrm{~mL}$ was mixed with $1 \mathrm{~mL}$ of ninhydrin color reagent and it was heated in water bath at $100^{\circ} \mathrm{C}$ for 16 minutes. The tubes were transferred to a cold water bath and $5 \mathrm{~mL}$ of dilution reagent was added, mixed and the absorbance was read at $575 \mathrm{~nm}$ against a blank containing $1 \mathrm{~mL}$ of water in place of sample.

\section{Microstructures}

Raw and extruded corn starch powders were examined with a field emission scanning electronic microscope (MIRA II LMH, Tescan USA, Inc., Cranberry Township, PA). The samples were fixed in stubs containing a gold-palladium alloy before observation. All samples were examined using at an accelerated voltage of $10 \mathrm{kV}$. 


\section{Fermentation and ethanol content}

Saccharomyces cerevisae (S. cerevisae, ATCC 24858) was used for ethanol fermentation. Yeast cells were maintained on YM agar medium (per liter) with $21 \mathrm{~g}$ YM powder, and $20 \mathrm{~g}$ agar. Yeast cells were cultured in a rotary shaker at $200 \mathrm{rpm}$ and $30^{\circ} \mathrm{C}$ for $48 \mathrm{hr}$ in a preculture media ( $2 \%$ glucose, $0.5 \%$ peptone, $0.3 \%$ yeast extract, $0.1 \%$ $\mathrm{KH}_{2} \mathrm{PO}_{4}$, and $0.05 \% \mathrm{MgSO}_{4} .7 \mathrm{H}_{2} \mathrm{O}$ (pH 5.5) [20]. Three grams of ground sample was suspended in $100 \mathrm{~mL}$ of fermentation medium containing (per liter): $3 \mathrm{~g}$ peptone, $1 \mathrm{~g} \mathrm{KH}_{2} \mathrm{PO}_{4}$, and $1 \mathrm{~g}\left(\mathrm{NH}_{4}\right)_{2} \mathrm{SO}_{4}$ at $\mathrm{pH}$ 3.8. This mixture was inoculated with $1 \mathrm{~mL}$ of activated yeast culture. Before and after fermentation the initial and residual reducing sugar contents were determined according to DNS method [14] using 3,5-dinitrosalicilic acid. Glucose solution was used as standard. The flasks were incubated in rotary shaker $(200 \mathrm{rpm})$ for $12,24,36,48,60$ and $72 \mathrm{hr}$ at $30^{\circ} \mathrm{C}$.

After fermentation, the samples $(5 \mathrm{~mL})$ were taken and centrifuged at $3000 \mathrm{rpm}$ for 20 minutes to remove the cells and the supernatants was used for determination of residual reducing sugar and ethanol content. Ethanol content was determined by redox titration method [21]. Ethanol content was calculated by subtracting the average volume of the sodium thiosulfate solution used for the sample from the average volume used for the blank titration. Conversion (\%) was calculated as: (initial reducing sugar content-residual reducing sugar content/initial sugar content $) \times 100[22]$.

\section{Experimental design and statistical analysis}

Completely randomized design (CRD) was performed to determine the effect of thermostable $\alpha$-amylase injection at melt temperatures 95,115 and $135^{\circ} \mathrm{C}$ on functional properties, ethanol content and conversion (\%) of extruded corn starch. Raw and extruded corn starches were determined in triplicates for functional properties, ethanol content and conversion (\%). The data were analyzed by using the SAS program (version 6.12, SAS).

\section{Results and Discussion}

\section{Reducing sugar and enzyme activity}

The residual enzyme activity of the extrudates at different melt temperatures 95,115 and $135^{\circ} \mathrm{C}$ was $3378.08,7361.43$ and 372.01 units/g enzyme respectively (Figure 1). The data showed that the highest residual enzyme activity was observed at $115^{\circ} \mathrm{C}$ followed by 95 and $135^{\circ} \mathrm{C}$, indicating that the enzyme was more active and more stable at $115^{\circ} \mathrm{C}$. Some other studies on the liquefaction of starch using extrusion-cooking mentioned that the enzyme in the extrudates was

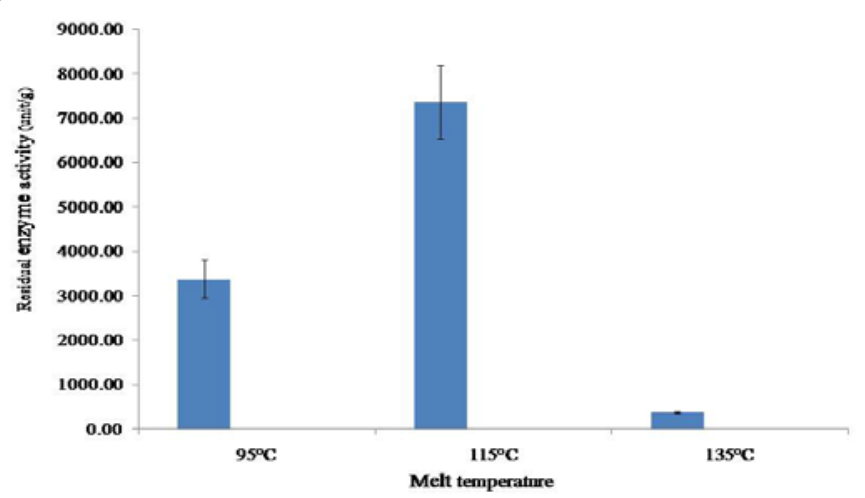

Figure 1: Residual enzyme activity of $\alpha$-amylase at different melt temperatures. still active after the extrudates discharged from the die. Our results are consistent with those of previous study [5]. The enzyme reaction would be continued if the temperature was controlled to be favorable for the reaction of the enzyme. The enzyme is highly thermostable in the absence of metal ions, active even at a temperature of $130^{\circ} \mathrm{C}[23]$.

\section{Functional properties}

The moisture content of raw and extruded corn starch with and without $\alpha$-amylase injection at different melt temperatures ranged between $3.29 \%$ and $8.66 \%$, those obtained values were less than $20 \%$ and were acceptable [24]. The moisture content of extruded corn starch with $\alpha$-amylase injection at 95 and $135^{\circ} \mathrm{C}$ was significantly increased $(\mathrm{p}<0.05)$ than those of without $\alpha$-amylase injection. However, there was no significant difference between extruded corn starch with and without $\alpha$-amylase injection at $115^{\circ} \mathrm{C}$. It is known that moisture acts as a plasticizer for retrogradation of starch and retrograded starch is less digestible [25]. The effect of a-amylase injection resulted in higher degree of starch hydrolysis which was shown by high total and reducing sugar contents in the extrudates (Table 1). There was significant difference $(\mathrm{p}<0.05)$ in total and reducing sugar contents between extruded corn starch with and without $\alpha$-amylase injection in tested melt temperatures. It is clearly seen that the enzyme activity of extruded corn starch at 95 and $115^{\circ} \mathrm{C}$ was higher than those of $135^{\circ} \mathrm{C}$. Similar to the trend observed in residual enzyme activity, total sugar and reducing sugar contents of extruded corn starch with $a$-amylase injection were significantly higher $(\mathrm{p}<0.05)$ than those of extruded corn starch without $\alpha$-amylase injection. The increase in reducing sugar content of the extrudates with $\alpha$-amylase injection was observed in the extrudates made from the highest moisture content (35\%) [26]. In this study, feed moisture content was adjusted to $30 \%$. A more recent study by Govindasamy et al. [5] reported that the degree of hydrolysis of sago starch in a twin-screw extruder was dependent on feed moisture content, enzyme concentration, and barrel temperature.

Protein digestibility has been used as a quality indicator for human foods and animal feeds. A protein with high digestibility potentially has better nutritional value than those with low digestibility. The protein digestibility of raw and extruded corn starch at different melt temperatures has been studied in vitro by using pepsin solution because of the in vitro pepsin digestibility was found to be correlated well with in vivo digestibility results [27], which make sense because humans and animals produce pepsin in their digestive tracts. In contracts, yeasts cannot produce any exoprotease for ethanol production. The data clearly showed that extrusion with $\alpha$-amylase injection at 95 and $115^{\circ} \mathrm{C}$ significantly increased $(\mathrm{p}<0.05)$ the protein digestibility of corn starch extrudates than those of without $\alpha$-amylase injection (Table 1 ). This may be due to two phenomena caused by extrusion with $\alpha$-amylase injection and protein denaturation, which may increase exposure of sites susceptible to enzymatic activity [28] and inactivation of trypsin and chemotrypsin inhibitors, leading to improved digestibility [29]. Duodu et al. [30] also reported that the addition of $\alpha$-amylase increased the protein digestibility of sorghum flour. However, the protein digestibility of raw corn starch was significantly higher $(p<0.05)$ than those of extruded corn starch. This may be due to the effect of extrusion. Other authors also reported that reduction in in vitro protein digestibility was the result of extrusion-cooking $[30,31]$. A strong linear correlation was observed between protein digestibility of normal grain sorghum samples and their fermentation efficiency in ethanol production [32].

Total phenolics content of raw and extruded corn starch at 
different melt temperatures is presented in table 1. Extrusion with $\alpha$-amylase injection at $115^{\circ} \mathrm{C}$ resulted in a significant decrease $(\mathrm{p}<0.05)$ in total phenolics content on average of $20 \%$ in comparison to the other melt temperatures 95 and $135^{\circ} \mathrm{C}$. However, there was no significant difference between the extruded corn starch with and without $\alpha$-amylase injection at 95 and $135^{\circ} \mathrm{C}$. Additionally, extrusion-cooking also resulted in a significant decrease $(\mathrm{p}<0.05)$ in total phenolics content of corn starch. Minimum amount of toxic compounds after pretreatment is one of the key factors to take into consideration for an effective pretreatment for low-cost and advanced pretreatment process [33] because pretreatment lead to generation of toxic compounds derived from sugar decomposition that could affect the proceeding hydrolysis and fermentation steps [34]. Extrusion cooking has also been reported that to cause important changes on phenolics compounds that might produce adverse effects for human and animal nutrition $[35,36]$.

\section{Free amino nitrogen}

The effect of $a$-amylase injection during extrusion significantly increased $(p<0.05)$ the amount of free amino nitrogen at melt temperatures 115 and $135^{\circ} \mathrm{C}$ (Table 1). However, there was no significant difference at $95^{\circ} \mathrm{C}$. Researchers have found that one of the factors limiting the production of high levels of ethanol by brewing yeast is nutritional deficiency [37]. Therefore, FAN content in a sample could be a useful indicator of a sample's performance in ethanol fermentation because FAN is an essential nutrient for yeast growth during fermentation [38,39]. Yan et al. (2010) [40] and Yan et al. [41] also showed similar results which agree with results reported by several other researchers [42,43]. Mullins and Nesmith [44] studied ethanol fermentation with high-tannin sorghum and revealed that the addition of nitrogen accelerated the ethanol fermentation rate. It is known that the nitrogen level, in defined medium containing glucose as carbon source, can be adjusted to give an increase in the rate of ethanol production during fermentation by Saccharomyces [45]. The addition of nitrogen, $300 \mathrm{mg}$ nitrogen/L total mass, as $\left(\mathrm{NH}_{4}\right)_{2} \mathrm{SO}_{4}$, gave the expected increase in the rate of ethanol production during $48 \mathrm{hr}$ fermentation. The mash without added nitrogen requires $96 \mathrm{hr}$ to obtain a similar value [44]. During extrusion with $a$-amylase injection, hydrolysis of starch might help the release of FAN content in the extruded sample [46,47] and increase FAN content in the mash, which would facilitate yeast growth, and increase the ethanol fermentation rate and efficiency. The nutritive quality as well as the sugar content of mashes is important for high fermentation capacity. Thus, extrusion with thermostable $\alpha$-amylase injection is an effective pretreatment method that could improve the bioconversion rate of corn starch into fermentable sugar.

\section{Microstructures}

The effect of $\alpha$-amylase injection during extrusion on the surface of extruded corn starch at different melt temperatures are shown in figure 2. The surface of the extruded corn starch granules with $\alpha$-amylase injection at $135^{\circ} \mathrm{C}$ had many pores with crackers (Figure 2E). This may suggest that the pores formed during extrusion may be readily accessible for enzyme during enzymatic saccharification. While those of extruded corn starch without $a$-amylase injection were very smooth and without bearing any pores (Figure $2 \mathrm{~F}$ ). Extruded corn starch with $a$-amylase injection at $95^{\circ} \mathrm{C}$ had increase in pore size but number of pore was lower than those of without $a$-amylase injection. Extensive serration, tunneling and surface erosion of extruded corn starch with $\alpha$-amylase injection at $115^{\circ} \mathrm{C}$ probably led to greater loss of crystallinity and more susceptible to enzyme digestion. Therefore, extruded corn starches with $\alpha$-amylase injection at $115^{\circ} \mathrm{C}$ were more susceptible to enzymatic digestion because water and enzyme can easily penetrate through these pores [48] resulting the highest reducing sugar yield for fermentation (Table 1). Production of smooth edges on the surface of extruded corn starch without $\alpha$-amylase injection at 115 and $135^{\circ} \mathrm{C}$ were linked to restricted access to the glycosidic bonds away from

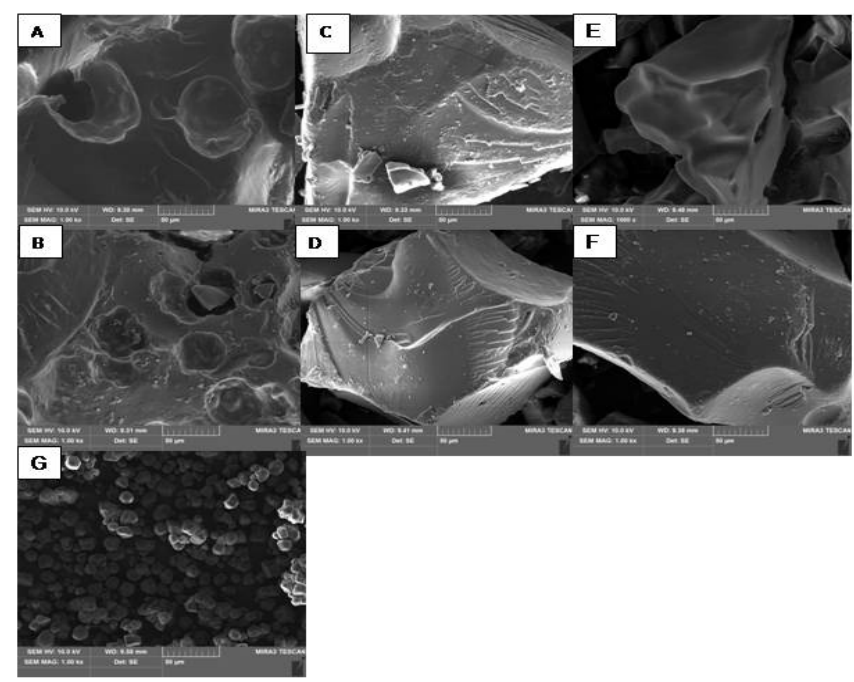

Figure 2: Microstmctures of raw and extruded com starch. A- $95^{\circ} \mathrm{C}$ jwith $\alpha$-amylase, $B-95^{\circ} \mathrm{C}$ without $\alpha$-amylase, $\mathrm{C}-115^{\circ} \mathrm{C}$ with $\alpha$-amylase, $\mathrm{D}-115^{\circ} \mathrm{C}$ without $\alpha$-amylase, $\mathrm{E}-135^{\circ} \mathrm{C}$ with $\alpha$-amylase, $\mathrm{F}-135^{\circ} \mathrm{C}$ without $\alpha$-amylase and G-raw com starch.

\begin{tabular}{|c|c|c|c|c|c|c|c|}
\hline Melt temp. $\left({ }^{\circ} \mathrm{C}\right)$ & $\alpha$-amylase injection & ${ }^{1} \mathrm{MC}$ & ${ }^{2} \mathrm{TS}(\mathrm{mg} / \mathrm{g})$ & ${ }^{3} \mathrm{RS}(\mathrm{mg} / \mathrm{g})$ & ${ }^{4}$ PD (\% of protein) & ${ }^{5} \mathrm{TPC}\left(\mathrm{mg}{ }^{6} \mathrm{GAE} / 100 \mathrm{~g}\right)$ & ${ }^{7} \mathrm{FAN}(\mathrm{mg} / \mathrm{ml})$ \\
\hline \multirow[t]{2}{*}{95} & with $\alpha$-amylase injection & $8.66^{b}$ & $114.04^{\mathrm{a}}$ & $4.65^{b}$ & $3.81^{\mathrm{b}}$ & $31.17^{c}$ & $287.63^{b}$ \\
\hline & without $\alpha$-amylase injection & $7.4^{\mathrm{c}}$ & $6.88^{d}$ & $0.73^{d}$ & $3.47^{\mathrm{c}}$ & $30.65^{c}$ & $285.95^{b}$ \\
\hline \multirow{2}{*}{115} & with a-amylase injection & $4.85^{\mathrm{d}}$ & $92.72^{\mathrm{b}}$ & $14.20^{\mathrm{a}}$ & $3.88^{\mathrm{b}}$ & $37.78^{c}$ & $373.88^{a}$ \\
\hline & without $\alpha$-amylase injection & $4.51^{\mathrm{de}}$ & $2.78^{\mathrm{e}}$ & $0.91^{d}$ & $3.46^{\mathrm{c}}$ & $56.65^{\mathrm{b}}$ & $308.96^{b}$ \\
\hline \multirow{3}{*}{135} & with $\alpha$-amylase injection & $4.29^{e}$ & $14.62^{\mathrm{c}}$ & $2.16^{\mathrm{c}}$ & $2.93^{d}$ & $58.80^{b}$ & $379.62 a$ \\
\hline & without $\alpha$-amylase injection & $3.29^{f}$ & $3.58^{\mathrm{e}}$ & $1.14^{d}$ & $3.06^{d}$ & $57.09^{b}$ & $275.26 b$ \\
\hline & raw corn starch & $12.34^{\mathrm{a}}$ & $3.07^{\mathrm{e}}$ & $0.68^{d}$ & $5.00^{\mathrm{a}}$ & $78.97^{\mathrm{a}}$ & $0.68^{d}$ \\
\hline
\end{tabular}

${ }^{1}$ moisture content, ${ }^{2}$ total sugar, ${ }^{3}$ reducing sugar, ${ }^{4}$ protein digestibility, ${ }^{5}$ total phenolics content, ${ }^{6}$ gallic acid equivalent, ${ }^{7}$ free amino nitrogen

Means of three replications, based on least significant difference (LSD) procedure at $\alpha=0.05$ level.

Means with the same letter ( $a$ and $b$ ) in the same column are not significantly different.

Table 1: Functional properties of raw and extruded corn starch at different extrusion conditions. 


\begin{tabular}{|c|c|c|c|c|c|c|c|}
\hline \multirow{2}{*}{ Melt temp. $\left({ }^{\circ} \mathrm{C}\right)$} & \multirow{2}{*}{ a-amylase injection } & \multicolumn{6}{|c|}{ fermentation period (hr) } \\
\hline & & 12 & 24 & 36 & 48 & 60 & 72 \\
\hline \multirow{2}{*}{95} & with $\alpha$-amylase & $17.86^{b}$ & $18.43^{\mathrm{bc}}$ & $17.26^{\mathrm{bc}}$ & $17.86^{\mathrm{b}}$ & $13.82^{\mathrm{abc}}$ & $10.95^{b c}$ \\
\hline & without $\alpha$-amylase & $16.13^{b}$ & $17.85^{c}$ & $19.58^{\mathrm{bc}}$ & $18.43^{b}$ & $13.25^{\mathrm{bc}}$ & $9.79^{\mathrm{cd}}$ \\
\hline \multirow[t]{2}{*}{115} & with a-amylase & $23.61^{\mathrm{ab}}$ & $27.64^{a}$ & $28.80^{\mathrm{a}}$ & $27.64^{\mathrm{a}}$ & $19.00^{\mathrm{a}}$ & $13.25^{\mathrm{a}}$ \\
\hline & without $\alpha$-amylase & $18.43^{b}$ & $19.58^{\mathrm{bc}}$ & $16.13^{b c}$ & $21.31^{\mathrm{b}}$ & $16.70^{\mathrm{ab}}$ & $12.10^{\mathrm{ab}}$ \\
\hline \multirow[t]{2}{*}{135} & with $\alpha$-amylase & $31.10^{\mathrm{a}}$ & $32.25^{\mathrm{a}}$ & $25.34^{\mathrm{ab}}$ & $21.88^{b}$ & $16.70^{\mathrm{ab}}$ & $10.94^{b c}$ \\
\hline & without $\alpha$-amylase & $29.95^{\mathrm{a}}$ & $25.91^{\mathrm{ab}}$ & $21.88^{b c}$ & $17.85^{\mathrm{b}}$ & $16.70^{\mathrm{ab}}$ & $10.37^{\mathrm{bcd}}$ \\
\hline
\end{tabular}

Means of three replications, based on least significant difference (LSD) procedure at $\alpha=0.05$ level.

Means with the same letter ( $a$ and $b$ ) in the same column are not significantly different.

Table 2: Ethanol content $(\mathrm{g} / 100 \mathrm{ml})$ of extruded corn starch at different fermentation periods.

\begin{tabular}{|c|c|c|c|c|c|c|c|}
\hline \multirow{2}{*}{$\begin{array}{l}\text { Melt temp. } \\
\quad\left({ }^{\circ} \mathrm{C}\right)\end{array}$} & \multirow{2}{*}{$\alpha$-amylase injection } & \multicolumn{6}{|c|}{ fermentation period (hr) } \\
\hline & & 12 & 24 & 36 & 48 & 60 & 72 \\
\hline \multirow[t]{2}{*}{95} & with $\alpha$-amylase & $55.14^{\mathrm{bc}}$ & $77.79^{a}$ & $85.26^{a}$ & $85.36^{a}$ & $85.38^{\mathrm{a}}$ & $87.10^{\mathrm{a}}$ \\
\hline & without $\alpha$-amylase & $44.87^{c}$ & $74.66^{\mathrm{abc}}$ & $86.04^{\mathrm{a}}$ & $86.37^{\mathrm{a}}$ & $86.56^{a}$ & $86.88^{a}$ \\
\hline \multirow{2}{*}{115} & with $\alpha$-amylase & $70.51^{a}$ & $76.98^{\mathrm{ab}}$ & $85.75^{\mathrm{a}}$ & $85.75^{a}$ & $85.84^{a}$ & $86.01^{a}$ \\
\hline & Without $\alpha$-amylase & $64.69^{\mathrm{ab}}$ & $67.08^{\mathrm{d}}$ & $74.16^{\mathrm{b}}$ & $74.26^{\mathrm{b}}$ & $74.41^{\mathrm{b}}$ & $74.72^{\mathrm{b}}$ \\
\hline \multirow{2}{*}{135} & with a-amylase & $66.84^{a}$ & $70.17^{\mathrm{cd}}$ & $79.09^{a}$ & $79.09^{a}$ & $86.83^{a}$ & $87.99^{a}$ \\
\hline & without $\alpha$-amylase & $60.50^{\mathrm{ab}}$ & $70.90^{\mathrm{bcd}}$ & $83.36^{\mathrm{a}}$ & $83.22^{\mathrm{a}}$ & $83.37^{\mathrm{a}}$ & $86.70^{a}$ \\
\hline
\end{tabular}

Means of three replications, based on least significant difference (LSD) procedure at $\alpha=0.05$ level.

Means with the same letter ( $a$ and $b$ ) in the same column are not significantly different.

Table 3: Conversion (\%) of extruded corn starch at different fermentation periods.

the immediate site of hydrolysis [49], which was indicated by lower content of reducing sugar (Table 1).

\section{Ethanol content}

Table 2 shows the amount of ethanol production from extruded corn starch with and without $\alpha$-amylase injection at different melt temperatures and different fermentation periods. In the present study, significant increase in ethanol production was achieved by the injection of thermostable $\alpha$-amylase injection during extrusion process at melt temperature $115^{\circ} \mathrm{C}$. The data clearly showed that thermostable $\alpha$-amylase injection gave higher ethanol content at melt temperature $115^{\circ} \mathrm{C}$ from fermentation periods $24-48 \mathrm{hr}$. This increase in ethanol content could be due to high enzyme activity that provides high reducing sugar and mild conditions of temperature for fermentation. As a result, fermentation inhibiting compounds are less and there is a reduction in the total environmental impact of the whole process [50,51]. In case of melt temperatures 95 and $135^{\circ} \mathrm{C}$, no significant difference in reducing sugar and ethanol content was observed between extruded corn starch with and without thermostable $a$-amylase injection in tested fermentation periods. In the case of $95^{\circ} \mathrm{C}$, decrease in reducing sugar and ethanol content may be due to incomplete gelatinization of corn starch during extrusion. Based on the findings of Planchot et al. [52] and Tester and Sommerville [53], it was expected that ungelatinized or crystalline starch would not be hydrolyzed completely by a-amylase. Consequently, it was expected that DE obtained after enzymatic hydrolysis would be affected by the degree of gelatinization. Grafelman and Meagher [54] and Gahlstrom et al. [55] reported that starch-water mixture with $17 \% \mathrm{w} / \mathrm{w}$ moisture content gelatinized at $120^{\circ} \mathrm{C}$. In this case, the hydrolysis temperature $\left(95^{\circ} \mathrm{C}\right)$ was low to complete gelatinization. For $135^{\circ} \mathrm{C}$, the reason could be inactivation of $\alpha$-amylase during extrusion and low reducing sugar for fermentation (Figure 1 and Table 1). The data showed that higher residual enzyme activity was observed only at melt temperature $115^{\circ} \mathrm{C}$ and consequently resulted in high reducing sugar and ethanol content (Figure 1, Tables 1 and 2). Jorgensen et al. [23] also reported that thermostable $\alpha$-amylase is highly active even at a temperature of $130^{\circ} \mathrm{C}$. The increase in ethanol production in case of fermentation periods (24$48 \mathrm{hr}$ ) as compared to other fermentation periods ( 60 and $72 \mathrm{hr}$ ) could be due to several reasons including the production of compounds other than ethanol like glycerol, acetic acid and $\mathrm{CO}_{2}$ during fermentation. The intra-cellular ethanol exerts high toxicity on yeasts, and nutrient deficiency at final stage of fermentation [56]. Similar to the trend observed in ethanol content, conversion (\%) of extruded corn starch with $\alpha$-amylase injection at $115^{\circ} \mathrm{C}$ was greater than those of extruded corn starch without $\alpha$-amylase injection in all incubation periods. In industrial bio-fuel production, extruded corn starch with thermostable a-amylase injection at $115^{\circ} \mathrm{C}$ could improve the bioconversion rate of corn starch because of its easy digestibility by enzyme and higher content of reducing sugar availability for fermentation.

\section{Conclusion}

Extrusion with thermostable $\alpha$-amylase injection at melt temperature $115^{\circ} \mathrm{C}$ gave enzyme accessible extrudates which showed optimum functional properties for fermentation substrate. Therefore, extrusion with thermostable $\alpha$-amylase injection at $115^{\circ} \mathrm{C}$ can improve functional properties of extruded corn starch for ethanol production (Table 3).

\section{Acknowledgement}

This research was supported by Training Program of Graduate Students in 
Citation: Myat L, Ryu GH (2013) Extrusion with Thermostable a-amylase Injection as Pretreatment Method for Ethanol Production from Corn Starch J Microb Biochem Technol 5: 047-053. doi:10.4172/1948-5948.1000099

Regional Innovation through the National Research Foundation of Korea (NRF) funded by the Ministry of Education, Science and Technology (2012307KJ).

\section{References}

1. Zhan X, Wang D, Bean SR, Mo X, Sun XS, et al. (2006) Ethanol production from supercritical-fluid-extrusion cooked sorghum. Ind Crops Prod 23: 304-310.

2. Zhan X, Wang D, Tuinstra MR, Bean S, Seib PA, et al. (2003a) Ethanol and lactic acid production as affected by sorghum genotype and location. Ind Crops Prod 18: 245-255.

3. Chang YK, El-Dash AA (2003) Extrusion-cooking of cassava starch as a pretreatment for its simultaneous saccharification and fermentation for ethanol production. Acta Alimentaria 32: 219-235.

4. Linko P, Hakulin S, Linko YY (1983) Extrusion cooking of barley starch for the production of glucose syrup and ethanol. J Cereal Sci 1: 275-284.

5. Govindasamy S, Campanella OH, Oates CG (1997) Enzymatic hydrolysis of sago starch in a twin-screw extruder. J Food Eng 32: 403-426.

6. van der Maarel MJ, van der Veen B, Uitdehaag JC, Leemhuis H, Dijkhuizen L (2002) Properties and applications of starch-converting enzymes of the alphaamylase family. J Biotechnol 28: 137-155.

7. Kennedy JF, Cadabla VM, White CA (1988) Enzymic starch utilization and genetic engineering. Trends Biotechnol 6: 184-189.

8. de Cordt S, Hendrickx M, Maesmans G, Tobback P (1994) The influence of polyalcohols and carbohydrates on the thermostability of alpha-amylase. Biotechnol Bioeng 43: 107-114.

9. Klibanov AM (1983) Stabilization of enzymes against thermal inactivation. Adv Appl Microbiol 29: 1-28.

10. Donovan JW (1979) Phase transitions of the starch-water system. Biopolymers 18: $263-275$

11. Lee YC, Kim KT (1990) Gelatinization and liquefaction of starch with a heat stable a-amylase. J Food Sci 55: 1365-1366

12. Saha B, Dien B, Bothast R (1998) Fuel ethanol production from corn fiber current status and technical prospects. Appl Biochem Biotechnol 70-72: 115 125

13. Yeung JS (2001) Extrusion cooking bo barley flour with and without thermostable a-amylase: Master thesis submitted to University of Alberta, Canada.

14. Miller GL (1959) Use of dinitrosalicylic acid reagent for determination of reducing sugar. Anal Chem 31: 426-428.

15. AOAC (1995) Official Methods of Analysis of AOAC International. (16thedn), Association of Official Analytical Chemists, Washington, DC, USA

16. Dubois M, Gilles KA, Hamilton JK, Rebers PA, Smith F, et al. (1956) Colorimetric method for determination of sugars and related substances. Analytical Chemistry 28: 350-356.

17. Mertz EE, Hassen MM, Cairns-Whittern C, Kirleis AW, Tu L, et al. (1984) Pepsin digestibility of proteins in sorghum and other major cereals. Proc Natl Acad Sci USA 81: 1-2.

18. Slinkard K, Singleton VL (1997) Total phenol analysis: Automation and comparison with manual methods. Am J Enol Vitic 28: 49-55.

19. European Brewery Conversion (EBC) (1987) Free amino nitrogen-ninhydrin colorimetric method. (4thedn), Brauerei-und Getranke-Rundschau, Zurich.

20. Zhan X, Wang D, Tuinstra MR, Bean S, Seib PA, et al. (2003b) Ethanol and lactic acid production as affected by sorghum genotype and location. Ind Crops Prod 18: 245-255.

21. Determination of ethanol concentration in aqueous solutions, University of Canterbury.

22. Dimitrellou D, Tsaousi K, Kourkoutas Y, Panas P, Kanellaki M, et al. (2008) Fermentation efficiency of thermally dried immobilized kefir on casein as starter culture. Process Biochemistry 43: 1323-1329.

23. Jorgensen S, Vorgias CE, Antranikian G (1997) Cloning, sequencing, characterization, and expression of an extracellular alpha-amylase from the hyperthermophilic archaeon Pyrococcus furiosus in Escherichia coli and Bacillus subtilis. J Biol Chem 272: 16335-16342.
24. Bergthaller W, Witt W, Goldau HP (1999) Potato starch technology. Starch 51 253-242.

25. Eliasson AC, Larsson K (1993) Cereal in breaking: a molecular colloidal approach. CRC Press, USA.

26. Budiasih W, Solihin Kim BS, Jae YC, Ryu GH (2007) Effect of feed moisture content on enzymatic hydrolysis of corn starch in twin-screw extruder and saccharification of the dried extrudates. Food Sci Biotechnol 16: 381-385.

27. MacLeon WC Jr, Lopez de Romaña G, Placko RP, Graham GG (1981) Protein quality and digestibility of sorghum in preschool children: balance studies and plasma free amino acids. J Nutr 111: 1928-1936.

28. Camire ME (2002) Chemical and nutritional changes in food during extrusion. Extruders in Food Applications. Riaz MN, (eds.). (1stedn), CRC Press, USA.

29. Alonso R, Aguirre A, Marzo F (1998) Effect of extrusion and conventiona processing methods on protein and antinutritional factor contents in pea seeds. Food Chem 63: 505-512.

30. Duodu KG, Nune A, Delgadillo I, Parder ML, Mills ENC, et al. (2002) Effect of grain structure and cooking on sorghum and maize in vitro protein digestibility. J Cereal Sci 35: 161-174

31. Hamaker BR, Kirleis AW, Mertz ET, Axtell JD (1986) Effect of cooking on the protein profiles and in vitro digestibility of sorghum and maize. J Agric Food Chem 34: 647-649.

32. Wang D, Bean S, McLaren J, Seib P, Madl R, et al. (2008) Grain sorghum is a viable feedstock for ethanol production. J Ind Microbiol Biotechnol 35: 313-320.

33. Yang B, Wyman CE (2008) Pretreatment: the key to the unlocking low-cost cellulosic ethanol. Biofuels Biopord Bioref 2: 26-40.

34. Oliva JM, Sáez F, Ballesteros I, González A, Negro MJ, et al. (2003) Effect of lignocellulosic degradation compounds from steam explosion pretreatment on ethanol fermentation by thermotolerant yeast Kluyveromyces marxianus. App Biochem Biotechnol 105-108: 141-153.

35. Anton AA, Ross KA, Beta T, Fulcher RG, Arntfield SD (2008) Effect of predehulling treatments on some physical and nutritional properties of navy and pinto beans (Phaseolus vulgaris L). LWT-Food Science and Technology 41 : 771-778.

36. Martin-Cabrejas MA, Sanfiz B, Vidal A, Molla E, Esteban R, et al. (2004) Effect of fermentation and autoclaving on dietary fiber fractions and antinutritional factors of beans (Phaseolus vulgaris L). J Agric Food Chem 52: 261-266.

37. Casey GP, Ingledew WM (1986) Ethanol tolerance in yeasts. Crit Rev Microbio 13: $219-280$.

38. Pickereel ATW (1986) The influence free alpha-amino nitrogen in sorghum beer fermentations. Journal of the Institute of Brewing 92: 568-571.

39. Taylor JRN, Boyd HK (1986) Free a-amino nitrogen production in sorghum beer mashing. J Sci Food Agric 37: 1109-1117.

40. Yan S, Wu X, Dahlberg J, Bean SR, MacRitchie F, et al. (2010) Properties of field-sprouted sorghum and its performance in ethanol production. J Cereal Sci 51: $374-380$

41. Yan S, Wu X, MacRitchie F, Wang D (2009) Germination-improved ethano fermentation performance of high-tannin sorghum in a laboratory dry-grind process. Cereal Chem 86: 597-600.

42. Casey GP, Magnus CA, Ingledew WM (1984) High-gravity brewing: effects of nutrition on yeast composition, fermentative ability, and alcohol production Appl Environ Microbiol 48: 639-646.

43. Lekkas C, Stewart GG, Hill A, Taidi B, Hodgson J (2005) The importance of free amino nitrogen in wort and beer. Tech Q Master Brew Assoc Am 42: 113-116.

44. Mullins JT, Nesmith CC (1987) Acceleration of the rate of ethanol fermentation by addition of nitrogen in high tannin grain sorghum. Biotechnol Bioeng 30 1073-1076.

45. Devine SJ, Slaughter JC (1980) FEMS Microbil Lett 9: 19.

46. Thomas KC, Ingledew WM (1990) Fuel alcohol production: effects of free amino nitrogen on fermentation of very-high gravity what mashes. Appl Environ Microbiol 56: 2046-2050.

47. Perez-Carrillo E, Serna-Saldivar SO, Alvarez MM, Cortes-Callejas ML (2008) Effect of sorghum decortications and use of protease before liquefaction with 
Citation: Myat L, Ryu GH (2013) Extrusion with Thermostable a-amylase Injection as Pretreatment Method for Ethanol Production from Corn Starch. J Microb Biochem Technol 5: 047-053. doi:10.4172/1948-5948.1000099

thermoresistant $\alpha$-amylase on efficiency of bioethanol production. Cereal Chem 85: 792-798.

48. Yan S, Wu X, Bean SR, Pedersen FF, Tesso T, et al. (2011) Evaluation of waxy grain sorghum for ethanol production. Cereal Chem 88: 589-595.

49. Wang WJ, Powell AD, Oates CG (1995) Pattern of enzymes hydrolysis in raw sago starch: effects of processing history. Carbohydr Polym 26: 91-97.

50. Coughlan MP, Ljungdahl LG (1988) Comparative biochemistry of fungal and bacterial cellulolytic enzymes: Biochemistry and Genetics of Cellulose Degradation. JP Aubert, PM Beguin.

51. Sun Y, Cheng J (2002) Hydrolysis of lignocellulosic materials for ethanol production: a review. Bioresour Technol 83: 1-11.
52. Planchot V, Colonna P, Buleon A (1997) Enzymatic hydrolysis of a-glucan crystallites. Carbohydrate Research 298: 319-326.

53. Tester RF, Sommerville MD (2001) Swelling and enzymatic hydrolysis of starch in low water systems. J Cereal Sci 33: 193-203.

54. Grafelman DD, Meagher MM (1995) Liquefaction of starch by a single-screw extruder and post-extrusion static-mixer reactor. J Food Eng 24: 529-542.

55. Gahlstrom DA, Bennett RC, Emmett RC, Harriott P, Laros T, et al. (1997) Liquidsolid operations and equipment: Perry's Chemical Engineers' Handbook, Perry RH, Green DW, Maloney JO, (eds.). (7thedn), McGraw-Hill, New York, USA.

56. Sols A, Gancedo C, Delafuente G (2002) The yeasts. In: Rose AH, Harrison, JS, (eds.). Academic Press, London, UK. 